\title{
PERBEDAAN REAKSI PEMBERIAN TRANSFUSI DARAH WHOOLE BLOOD (WB) DAN PACKED RED CELL (PRC) PADA PASIEN SECTIO CAESARE
}

\author{
Rahmatul Fuadda $^{1^{*}}$ Neila Sulung ${ }^{2}$ Lisa Vina Juwita ${ }^{3}$ \\ Keperawatan STIKes Fort De Kock \\ Email: rahmatulfuadda@gmail.com
}

Submitted: 09-12-2016, Reviewer: 10-12-2016, Accepted: 10-12-2016

\begin{abstract}
ABSTRAK
Transfusion reaction is the reaction of the recipient's body to blood donors, blood transfusion reactions can be mild to severe, and could be either fast, medium and slow. Hospital Dr. Achmad Darwis District Lima Puluh Kota every month UTDRS blood for transfusion are 45 to 55 bags. Survey of 30 patients who received a blood transfusion, there are 10 people have reactions such as fever of 4 people, as many as 4 people dizzy, urtikariat (itching) as much as one person and as many as three people shivering. The aim of research to find out the difference Reaction Giving Whoole Blood Transfusion Blood (WB) and Packed Red Cell (PRC) in Patients Sectio Caesare (SC). Type pre-experimental study, the design of Static Group Comparison. The population was patients post SC who receive blood transfusion, with sampling purposive sampling of 20 people. The data collection was done by direct observation, then processed and analyzed using independent t-test. Results that the average transfusion reactions in patients receiving blood transfusions WB is 1.30 and the patients who receive blood transfusion $\mathrm{PRC}$ is 0.40. The results of the bivariate no difference Whoole blood transfusion reaction Blood (WB) and Packed Red Cell (PRC) in Patients with Post Sectio Caesarea (SC) (p = 0.009). It was concluded that there is a difference of transfusion reactions in blood transfusions WB and blood transfusions PRC. Expected to medicine and nurse to be more selective in giving blood transfusions to patients and intensive control of blood transfusion process, so that a transfusion reaction can be immediately known. .
\end{abstract}

Keywords: transfusion reactions, Whoole Blood (WB), Packed Red Cell (PRC)

\begin{abstract}
ABSTRAC
Reaksi Transfusi adalah reaksi tubuh resipien terhadap darah donor, reaksi transfusi darah dapat ringan sampai berat, dan dapat berupa reaksi cepat, sedang, dan lambat. RSUD Dr. Achmad Darwis Kabupaten Lima Puluh Kota setiap bulannya UTDRS mengeluarkan darah untuk transfusi berjumlah 45 sampai 55 kantong. Survey terhadap 30 orang pasien yang mendapatkan transfusi darah, terdapat 10 orang mengalami reaksi berupa demam sebanyak 4 orang, pusing sebanyak 4 orang, menggigil sebanyak 3 orang dan urtikariat (gatal-gatal) sebanyak 1 orang. Tujuan penelitian untuk mengetahui Perbedaan Reaksi Pemberian Transfusi Darah Whoole Blood (WB) dan Packed Red Cell (PRC) pada Pasien Sectio Caesare (SC). Jenis penelitian pra eksperimen, dengan rancangan Statis Group Comparison. Populasi adalah pasien post SC yang mendapatkan transfusi darah, dengan pengambilan sampel secara purposive sampling sebanyak 20 orang. Pengumpulan data dilakukan dengan cara observasi langsung, kemudian diolah dan dianalisa menggunakan $t$-test independent. Didapatkan hasil rata- rata reaksi transfusi pada pasien yang mendapatkan transfusi darah WB adalah 1,30 dan pasien yang mendapatkan transfusi darah PRC adalah 0,40. Terdapat perbedaan reaksi pemberian transfusi darah Whoole Blood (WB) dan Packed Red Cell (PRC) pada Pasien Post Sectio Caesarea (SC) ( $p=$ 0,009). Disimpulkan bahwa ada perbedaan reaksi transfusi pada transfusi darah WB dan transfusi darah PRC. Diharapkan dokter dan perawat agar lebih selektif dalam memberikan darah transfusi pada pasien dan intensif dalam mengontrol proses transfusi darah, sehingga adanya reaksi transfusi dapat segera diketahui.
\end{abstract}

Kata Kunci : Reaksi Transfusi, Whoole Blood(WB), Packed Red Cell (PRC) 


\section{PENDAHULUAN}

Dalam rangka mewujudkan derajat kesehatan masyarakat yang setinggitingginya, perlu diselenggarakan berbagai upaya kesehatan yang dilaksanakan melalui kegiatan pencegahan penyakit, pencegahan kesehatan, pengobatan penyakit dan pemulihan kesehatan (Menkes RI 2011, p.1). Salah satu bentuk upaya kesehatan tersebut adalah melalui transfusi darah. Upaya kesehatan Transfusi Darah adalah upaya kesehatan yang bertujuan agar penggunaan darah berguna bagi keperluan pengobatan dan pemulihan kesehatan. Kegiatan tranfusi itu mencakup antara lain pengerahan donor, penyumbangan darah, pengambilan, pengamanan, pengolahan, penyimpanan, dan penyampaian darah kepada pasien (Astuti \& Laksono 2013, p.1).

Menurut data World Health Organization (WHO), darah nasional suatu negara pertahunnya harus berjumlah 2 persen dari total penduduk. WHO melaporkan bahwa $80 \%$ dari populasi di negara-negara maju menggunakan donor darah yang aman. Sebaliknya, hanya $20 \%$ dari populasi di negara-negara berkembang, yang menggunakan donor darah yang aman (Samsiarah 2011, p.106). Penyediaan darah oleh Palang Merah Indonesia (PMI) baru tercapai $0,7 \%$ dari jumlah penduduk (1,7 juta kantung) dan persediaan darah baru mencukupi kebutuhan 2 hari. Target WHO yakni 2 $\%$ jumlah penduduk atau 4 juta kantung per tahun dan persediaan darah mencukupi kebutuhan 4 hari (Astuti \& Laksono 2013, p.iii). Di Indonesia butuh 4 juta kantong darah. Tapi, yang sudah terkumpul untuk saat ini baru 3,5 juta. Darah di PMI sudah terkumpul 2.250.000 kantung darah lengkap. Yang nantinya akan dibagi menjadi 3. Sel darah merah, trombosit, plasma. Sehingga secara keseluruhan terkumpul 3,5 juta kantong darah (Prawira 2013, p.1).

Transfusi darah pada hakekatnya adalah pemberian darah atau komponen darah dari satu individu (donor) ke individu lainnya (resipien), dimana dapat menjadi penyelamat nyawa, tapi dapat pula berbahaya dengan berbagai komplikasi yang dapat terjadi, sehingga transfusi darah hendaklah dilakukan dengan indikasi yang jelas dan tepat sehingga diperoleh manfaat yang jauh lebih besar dari pada resiko yang mungkin terjadi (FK-UI 2006, p.685). Untuk melayani masalah transfusi darah ini, di Indonesia dibentuk Unit Transfusi Darah (UTD). UTD adalah fasilitas pelayanan kesehatan yang menyelenggarakan donor darah, penyediaan darah, dan pendistribusian darah (Astuti \& Laksono 2013, p.4). Beberapa macam komponen darah transfusi, yaitu Whole blood (darah lengkap), Packed Red Cell (PBC), Plasma Beku Segar (Fresh Frozen Plasma), Trombosit, Kriopresipitat. Whole blood biasanya disediakan hanya untuk transfusi pada perdarahan masif. Whole blood biasa diberikan untuk perdarahan akut, shock hipovolemik serta bedah mayor dengan perdarahan lebih dari 1500 $\mathrm{ml}$. PRC mengandung hemoglobin yang sama dengan whole blood, bedanya adalah pada jumlah plasma, dimana PRC lebih sedikit mengandung plasma. PRC biasa diberikan pada pasien dengan perdarahan lambat, pasien anemia tau pada kelainan jantung (Astuti dan Laksono 2013, p.9).

Transfusi darah dapat menghasilkan reaksi transfusi. Reaksi Transfusi adalah reaksi tubuh resipien terhadap darah donor, reaksi transfusi darah dapat ringan sampai berat, dan dapat berupa reaksi cepat, sedang, dan lambat. Standar angka kejadian reaksi transfusi adalah <0,01\% (Muhiddin 2013, p.2). Sebuah penelitian melaporkan bahwa reaksi transfusi yang tidak diharapkan ditemukan pada $6,6 \%$ resipien, dimana sebagian besar $(55 \%)$ berupa demam. Gejala lain adalah menggigil tanpa demam sebanyak $14 \%$, alergi $20 \%$, hepatitis serum positif $6 \%$, reaksi hemolitik $4 \%$ dan overload sirkulasi $1 \%$ (Sudoyo dkk 2006, p.682).

Adanya reaksi transfusi ini telah juga dibuktikan pada penelitian Samsiarah (2011) di Rumah Sakit Umum Dr. Sardjito Yogyakarta, disimpulkan bahwa reaksi 
transfusi darah lebih sering terjadi pada operasi emergensi dibandingkan operasi elektif. Reaksi transfusi lebih sering ditimbulkan oleh transfusi WB dibandingkan PRC. Jenis reaksi transfusi yang terjadi adalah takikardia $(0,09 \%)$, demam $(46,5 \%)$, mual $(0,08 \%)$, ruam $(15,15 \%)$, hypercalemia $(0,08 \%)$ dan pruritus $(13,13 \%)$.

Beberapa faktor melibatkan terjadinya reaksi transfusi selama atau setelah transfusi darah. Dalam hal ini jenis penelitian operasi (darurat atau operasi elektif), jenis darah ditransfusikan (WB, PRC atau FFP) dan jumlah Unit darah yang diberikan (pasca transfusi $\mathrm{Hb}$ rate) yang terbukti merupakan faktor yang terlibat pada kejadian reaksi transfusi (Samsiara 2011, p.110). Bila telah diketahui bahwa seseorang pasien mengalami reaksi transfusi, penting untuk memastikan bahwa transfusi itu sudah dihentikan, dokter yang bersangkutan sudah diberitahu, sampel-sampel yang diperlukan telah diambil untuk diperiksa di laboratorium (Depkes RI 2003, p.43).

Rumah Sakit Umum Daerah Dr. Achmad Darwis Kabupaten Lima Puluh Kota sudah memiliki Unit Transfusi Darah, dimana setiap bulannya UTDRS mengeluarkan darah untuk transfusi berjumlah 45 sampai 55 kantong. Peneliti mengamati bahwa sering terjadi komplain dari keluarga pasien karena $\mathrm{HB}$ pasien METODE PENELITIAN

Jenis penelitian ini adalah penelitian pra eksperimen, dengan rancangan perbandingan kelompok statis (Statis Group Comparison). Penelitian dilaksanakan pada bulan Maret - April 2016 di RSUD Dr. Achmad Darwis Kabupaten Lima Puluh Kota. Populasi adalah pasien post operasi yang mendapatkan transfusi darah, dengan tidak juga bertambah setelah dilakukan transfusi darah, sehingga mereka harus mencari tambahan darah ataupun pendonor lain, ataupun karena transfusi yang harus dihentikan karena adanya reaksi setelah transfusi tersebut.

Survey yang dilakukan pada bulan November 2015, diketahui bahwa diantara 30 orang pasien yang mendapatkan transfusi darah, terdapat 10 orang mengalami reaksi. Reaksi yang terjadi berupa demam sebanyak 4 orang, pusing sebanyak 4 orang, urtikariat (gatal- gatal) sebanyak 1 orang dan menggigil sebanyak 3 orang. Terjadinya komplikasi transfusi berupa reaksi hemolitik (segera) tersebut disebabkan karena pasien harus mendapatkan transfusi darah dalam jumlah banyak setelah Sectio Caesarea (SC). Akibat dari reaksi tersebut maka dokter memerintahkan untuk menghentikan transfusi atau memberikan transfusi dengan mengganti jenis darah yang lain (Laporan Bulanan UTDRS Dr. Achmad Darwis, 2015).

Berdasarkan uraian di atas, maka peneliti tertarik untuk mengetahui tentang perbedaan reaksi pemberian transfusi darah Whoole Blood (WB) dan Packed Red Cell (PRC) pada Pasien Post Sectio Caesarea (SC) di RSUD Dr. Achmad Darwis Kabupaten Lima Puluh Kota tahun 2016

pengambilan sampel secara purposive sampling berjumlah 20 orang. Pengumpulan data dilakukan dengan cara observasi langsung terhadap reaksi transfusi darah yang terjadi pada pasien. Analisa data yang digunakan adalah analisa univariat dan bivariat menggunakan uji statistik t-test independent. 


\section{HASIL DAN PEMBAHASAN}

Hasil penelitian yang dilakukan RSUD Dr. Achmad Darwis Kabupaten Lima Puluh Kota dalam melihat perbedaan antara reaksi trafusi pada yang mendapatkan WB dan PRC

\section{Reaksi Transfusi pada Pasien yang Mendapatkan Darah WB}

Hasil penelitian diketahui rata-rata reaksi transfusi pada pasien yang mendapatkan transfusi darah WB adalah 1,30, dengan standar deviasi 0,823 . Reaksi terendah adalah 0 dan reaksi tertinggi 2. Dari hasil estimasi disimpulkan bahwa 95\% diyakini rata-rata reaksi transfusi pada pasien yang mendapatkan transfusi darah WB adalah 0,71 1,89 .

Whole blood biasanya disediakan hanya untuk transfusi pada perdarahan masif. Whole blood biasa diberikan untuk perdarahan akut, shock hipovolemik serta bedah mayor dengan perdarahan lebih dari $1500 \mathrm{ml}$. Whole blood akan meningkatkan kapasitas pengangkutan oksigen dan peningkatan volume darah. Transfusi satu unit whole blood akan meningkatkan hemoglobin $1 \mathrm{~g} / \mathrm{dl}$ (Astuti dan Laksono 2013, p.9). Menurut Sudoyo, dkk (2006, p.685) indikasi pemberian darah lengkap (whoole blood) adalah dengan tujuan untuk meningkatkan jumlah sel darah merah dan volum plasma dalam waktu yang bersamaan, misalnya pada perdarahan aktif dengan kehilangan darah lebih dari $25-30 \%$ volume darah total. Tetapi pemberian darah lengkap pada keadaan tersebut tidak menjadi pilihan utama, karena pemulihan segera volume darah pasien jauh lebih penting daripada penggantian sel darah merah, sedangkan menyiapkan darah untuk transfusi memerlukan waktu.

Biasanya pada reaksi transfusi terjadi reaksi segera yang mengancam nyawa, reaksi ini terjadi pada saat proses transfusi berlangsung, manifestasinya antara lain kemerahan pada wajah yang segera timbul, rasa hangat di vena yang menerima darah, demam dan menggigil, nyeri dada dan pinggang, nyeri abdomen disertai mual dan muntah, penurunan tekanan darah disertai peningkatan kecepatan denyut jantung, sesak napas (Handayani \& Hariwibowo 2008 p.67). Bila telah diketahui bahwa seseorang pasien mengalami reaksi transfusi, penting untuk memastikan bahwa Transfusi itu sudah dihentikan, Dokter yang bersangkutan sudah diberitahu, Sampel-sampel yang diperlukan telah diambil untuk diperiksa di laboratorium, yaitu antara lain, Sampel darah yang beku dan tidak beku dari pasien sesegera mungkin setelah transfuse, Sisa sel darah merah dan plasma dari darah donor yang ditransfusikan, Spesimen pertama urin pasien sesudah tranfusi dilakukan (Depkes RI 2003, p.43.

Penelitian yang dilakukan

oleh Nency \& Sumanti (2011) tentang Latar Belakang Penyakit pada Penggunaan Transfusi Komponen Darah pada Anak di RSUP dr. Kariadi Semarang, diketahui bahwa transfusi darah WB diberikan pada pasien dengan penyakit dasar sepsis, tindakan perioperatif, keganasan non leukemia, dan penyakit jantung.

Menurut asumsi peneliti, reaksi transfusi darah yang diteliti oleh peneliti hanya pada kolf I, sedangkan reaksi untuk kolf kedua, ketiga dan selanjutnya belum dilakukan penelitian. Reaksi tersebut merupakan bentuk reaksi karena antibodi leukosit, antibodi trombosit atau senyawa pirogen. Hal ini dapat dilihat dari reaksi yang banyak dialami pasien adalah berupa rasa hangat di vena yang menerima darah dan gatal-gatal pada kulit. Gatal-gatal tersebut dapat terjadi karena kemungkinan darah yang ditransfusikan tersebut berasal dari 
donor yang memiliki riwayat alergi. Untuk meminimalisir reaksi ini, maka penting bagi petugas untuk mendata setiap pendonor guna mengantisipasi timbulnya reaksi alergi (gatal-gatal) pada saat transfusi darah. Reaksi lain yang dialami pasien adalah demam dan menggigil. Bagi pasien yang mengalami reaksi demam dan menggigil, kemerahan pada wajah yang segera timbul, dan sesak nafas, maka proses transfusi langsung dihentikan. Namun bagi pasien yang mengalami reaksi rasa panas di vena, reaksi masih tetap dilanjutkan. Pada pasien yang mengalami rasa gatal pada kulit, umumnya terjadi setelah transfusi selesai. Bagi pasien yang mengalami 2 reaksi transfusi disebabkan reaksi yang mereka rasakan adalah berupa rasa panas di vena, karena proses transfusi darah yang lama akibat tetesan infus tidak lancar. Hal ini juga berdampak pada timbulnya gatal-gatal pada kulit setelah proses transfusi.

\section{Reaksi Transfusi pada Pasien yang Mendapatkan Darah PRC}

Hasil penelitian diketahui ratarata reaksi transfusi pada pasien yang mendapatkan transfusi darah PRC adalah 0,40, dengan standar deviasi 0,516. Reaksi terendah adalah 0 dan reaksi tertinggi 1. Dari hasil estimasi disimpulkan bahwa 95\% diyakini ratarata reaksi transfusi pada pasien yang mendapatkan transfusi darah PRC adalah $0,030-0,77$.

Sel darah merah pekat berisi eritrosit, trombosit, lekosit dan sedikit plasma. Sel darah merah ini didapat dengan memisahkan sebagian besar plasma dari darah lengkap, sehingga diperoleh sel darah merah dengan nilai hematokrit $60-70 \%$. Volume diperkirakan 150-400 ml tergantung besarnya kantung darah yang dicapai, dengan massa sel darah merah 100$200 \mathrm{ml}$. Sel darah merah pekat ini berguna untuk meningkatkan jumlah sel darah merah pada pasien yang menunjukkan gejala anemia, yang hanya memerlukan massa sel darah merah pembawa oksigen saja (Sudoyo, dkk 2006, p.686).

PRC mengandung hemoglobin yang sama dengan whole blood, bedanya adalah pada jumlah plasma, dimana PRC lebih sedikit mengandung plasma. PRC biasa diberikan pada pasien dengan perdarahan lambat, pasien anemia atau pada kelainan jantung (Astuti dan Laksono 2013, p.9).

Penelitian yang dilakukan oleh Nency \& Sumanti (2011) tentang Latar Belakang Penyakit pada Penggunaan Transfusi Komponen Darah pada Anak di RSUP dr. Kariadi Semarang, diketahui bahwa transfusi darah PRC diberikan pada pasien dengan penyakit dasar thalasemia, leukimia, sepsis, tindakan perioperatif, keganasan non leukemia, sindrom syok dengue, anemia aplastik, hemofilia, penyakit jantung dan penyakit ginjal.

Menurut asumsi peneliti, terjadinya reaksi transfusi pada pasien yang mendapatkan transfusi darah PRC disebabkan adanya riwayat alergi dari pendonor yang tidak diketahui, sehingga menimbulkan gatal-gatal pada pasien yang menerima transfusi. Sementara reaksi hangat di vena, demam dapat dipengaruhi oleh transfusi eritrosit yang rusak akibat paparan dekstrose $5 \%$, injeksi air ke dalam sirkulasi, transfusi darah yang lisis, transfusi darah dengan pemanasan berlebihan, transfusi darah beku, transfusi darah yang terinfeksi, dan transfusi darah dengan tekanan tinggi.

Reaksi-reaksi tersebut terjadi sebagai respon tubuh terhadap sel-sel darah putih dalam darah yang disumbangkan. Hal ini terjadi pada pasien yang pernah mendapat transfusi sebelumnya dan wanita pernah beberapa kali mengalami 
kehamilan. Oleh sebab itu, pada pasien yang mengalami reaksi demam atau yang beresiko terhadap reaksi tranfusi lainnya biasanya diberikan produk darah yang leukositnya telah dikurangi. Artinya, sel-sel darah putih telah hilang setelah melalui filter atau cara lainnya.

\section{Analisis Bivariat}

Hasil penelitian diketahui bahwa rata-rata reaksi transfusi pada pemberian transfusi darah WB adalah 130 dengan standar deviasi 0,823 . Sedangkan pada pemberian transfusi darah PRC diperoleh dararata 0,40 dengan standar deviasi 0,516 . Terlihat perbedaan rata-rata (mean different) rata-rata reaksi transfusi darah WB dengan PRC adalah 0,90 dengan nilai $t=2,929$. Dapat disimpulkan bahwa ada perbedaan reaksi pemberian transfusi darah Whoole Blood (WB) dan Packed Red Cell (PRC) pada Pasien Post Sectio Caesarea (SC) di RSUD Dr. Achmad Darwis Kabupaten Lima Puluh Kota tahun 2016, nilai $\mathrm{p}=$ $0,009(\mathrm{p}<0,05)$.

Reaksi transfusi adalah suatu perusakan secara imunologis sel-sel darah merah inkompatibel yang diperoleh melalui transfusi darah. Biasanya pada reaksi transfusi terjadi reaksi segera yang mengancam nyawa, reaksi ini terjadi pada saat proses transfusi berlangsung, manifestasinya antara lain kemerahan pada wajah yang segera timbul, rasa hangat di vena yang menerima darah, demam dan menggigil, nyeri dada dan pinggang, nyeri abdomen disertai mual dan muntah, penurunan tekanan darah disertai peningkatan kecepatan denyut jantung, dan sesak napas (Handayani \& Hariwibowo 2008 p.67).

Sejalan dengan penelitian Samsiarah (2011) tentang perbandingan reaksi transfusi darah di Rumah Sakit Umum Dr. Sardjito Yogyakarta, diketahui bahwa reaksi transfusi lebih sering ditimbulkan oleh transfusi WB dibandingkan PRC $(\mathrm{p}=0,001)$, dimana reaksi transfusi lebih banyak pada WB (84,9\%) dibandingkan PRC $(25,1 \%)$ yaitu berupa reaksi Takikardia, demam, mual, ruam, hiper calcemia dan pruritus dengan ringan sampai sedang parah.

Menurut asumsi peneliti, adanya perbedaan reaksi transfusi pada pasien yang mendapatkan transfusi darah WB dengan pasien yang mendapat transfusi darah PRC disebabkan karena pada transfusi darah WB seluruh komponen darah diberikan pada pasien, karena plasma mengandung bermacam-macam protein, zat kimia, faktor-faktor pembeku dan kaya dengan zat metabolik. Hal ini menyebabkan terjadinya reaksi transfusi pada pasien yang mendapatkan darah WB yaitu berupa kemerahan apda wajah yang segera timbul 1 orang, rasa hangat di vena yang menerima darah 3 orang, demam dan menggigil 1 orang, nyeri abdomen diserta mual dan muntah 1 orang, penurunan tekanan darah disertai peningkatan kecepatan denyut jantung 1 orang dan gatal-gatal pada kulit 5 orang.

Pada transfusi darah PRC, darah sudah disaring dan sebagian besar plasma sudah dipisahkan dari darah lengkap, akhirnya diperoleh sel darah merah dengan nilai hematokrit 60 - $70 \%$. Hal tersebut menyebabkan PRC berfungsi untuk mengurangi penularan penyakit dan mengurangi reaksi imunologis, sehingga pasien sangat jarang mengalami reaksi transfusi. Reaksi transfusi yang dialami pasien pada pemberian darah PRC ini berupa kemerahan pada wajah ayng segera timbul 1 orang, demam dan menggigil 1 orang, dan gatal-gatal pada kulit 1 orang. 
Oleh sebab itu, untuk meminimalisir reaksi transfusi pada transfusi darah WB diperlukan tindakan pencegahan sebelum transfusi dimulai, seperti konfirmasi ulang ke ruangan atau dokter terkait pemakaian darah WB, karena dengan memakai darah WB memungkinkan terjadinya berbagai reaksi transfusi. Disamping hal tersebut, transfusi darah PRC memiliki keuntungan dibandingkan transfusi darah WB bagi pasien post SC yang tidak mengalami perdarahan hebat, seperti kemungkinan overload sirkulasi menjadi minimal, reaksi transfusi akibat komponen plasma menjadi kurang, reaksi transfusi akibat antibodi donor menjadi minimal, akibat samping volume antikoagulan

\section{KESIMPULAN}

Rata-rata reaksi transfusi pada pasien yang mendapatkan transfusi darah WB adalah 1,30. Rata-rata reaksi transfusi pada pasien yang mendapatkan transfusi darah PRC adalah 0,40 Ada perbedaan reaksi pemberian transfusi darah Whoole Blood (WB) dan Packed Red Cell (PRC) pada Pasien Post Sectio Caesarea (SC) di RSUD Dr. Achmad Darwis kabupaten Lima Puluh Kota tahun 2016, nilai $\mathrm{p}=0,009(\mathrm{p}<0,05)$. Diharapkan pada dokter dan perawat agar lebih selektif dalam memberikan darah transfusi pada pasien dan intensif dalam mengontrol proses transfusi darah, sehingga adanya reaksi transfusi dapat segera diketahui.

\section{DAFTAR REFERENSI}

Astuti dan Laksono. 2013. Keamanan Darah di Indonesia. Surabaya. Health Advocacy

Depkes RI. 2003. Buku Pelayanan Transfusi Darah: Mutu dan Keamanan dalam Penyediaan Darah. Jakarta. Depkes RI

DepKes RI. 2003. Buku Pedoman Pelayanan Transfusi Darah : yang berlebihan menjadi minimal, dan meningkatnya daya guna pemakaian darah karena sisa plasma dapat dibuat lagi menjadi komponen-komponen yang lain.

Dapat disimpulkan bahwa transfusi darah PRC jauh lebih baik dan memiliki resiko yang kecil dibandingkan dengan transfusi darah WB. Namun demikian, pemberian darah WB ini banyak juga dilakukan karena stok dara di UTD tidak selalu ada, sehingga digunakan darah baru yang didonorkan oleh keluarga. Terkadang darah yang sudah di PRC kan dikembalikan lagi ke UTD dengan akasan transfusi darah tersebut menimbulkan demam pada pasien.

Serologi Golongan Darah. Jakarta. Depkes Ri

Handayani dan Hariwibowo. 2008. Buku Ajar Asuhan Keperawatan pada Pasien dengan Gangguan Sistem Hematologi. Jakarta. Salemba Medika

Menkes RI. 2011. Peraturan Pemerintah Republik Indonesia Nomor 7 Tahun 2011 tentang Pelayanan Darah. Jakarta. Kemenkes RI

Muhiddin, Triyono dan Sukorini. 2013. Indikator Kualitas Pelayanan Darah Bank Darah RSUP Dr. Wahidin Sudirohusodo Makassar. Fakultas KesehatanUniversitas Makassar

Nency, YM dan Sumanti, D. 2011. Latar Belakang Penyakit pada Penggunaan Transfusi Komponen Darah pada Anak di RSUP $d r$. Kariadi Semarang . Sari Pediatri Vol. 13 No. 3 Oktober 2011

Prawira, AE. 2013. Kesadaran Masyarakat untuk Donor Darah Masih Kurang. http://health.liputan6.com/read/511 
127/kesadaran-masyarakat-untukdonor-darah- masih-kurang

Samsiarah, H. 2011. A comparison study on the blood transfusion reaction between the elective and the emergency operation's patients. Med Sci Volume 43, No. 2, June 2011: 105-111

Sudoyo, dkk. 2006. Buku Ajar Ilmu Penyakit Dalam. Jakarta.

Departemen Ilmu Penyakit Dalam.

FK-UI 
Volume 1.No.3 Tahun 2016

Jurnal Human Care 